\title{
Transmission of bovine viral diarrhea virus among white-tailed deer (Odocoileus virginianus)
}

\author{
Thomas Passler ${ }^{1}$, Stephen S. DitchKoff ${ }^{2}$, M. Daniel Givens ${ }^{1}$, Kenny V. Brock ${ }^{1}$, \\ Randy W. DeYoung ${ }^{3}$, Paul H. WAlz ${ }^{1 *}$ \\ ${ }^{1}$ College of Veterinary Medicine, JT Vaughan Large Animal Teaching Hospital, Auburn University, \\ Auburn, AL 36849, USA \\ ${ }^{2}$ School of Forestry and Wildlife Sciences, Auburn University, Auburn, AL 36849, USA \\ ${ }^{3}$ Caesar Kleberg Wildlife Research Institute, Texas A\&M University-Kingsville, Kingsville, TX 78363, USA
}

(Received 16 July 2009; accepted 17 November 2009)

\begin{abstract}
Cattle persistently infected (PI) with bovine viral diarrhea virus (BVDV), a pestivirus in the family Flaviviridae, are an important source of viral transmission to susceptible hosts. Persistent BVDV infections have been identified in white-tailed deer (Odocoileus virginianus), the most abundant freeranging ruminant in North America. As PI deer shed BVDV similarly to PI cattle, maintenance of BVDV within white-tailed deer populations may be possible. To date, intraspecific transmission of BVDV in whitetailed deer has not been evaluated, which prompted this study. Six pregnant white-tailed deer were captured in the first trimester of pregnancy and cohabitated with a PI white-tailed deer. Cohabitation with the PI deer resulted in BVDV infection in all does, as indicated by seroconversion. All does gave birth to live fawns and no reproductive losses were observed. At birth, evidence of BVDV infection was identified in two singlet fawns, of which one was determined to be PI by repeated serum reverse transcription nested PCR, whole blood virus isolation and immunohistochemistry. This study demonstrates for the first time that BVDV transmission may occur among white-tailed deer. The birth of a PI fawn through contact to a PI white-tailed deer indicates that under appropriate circumstances, BVDV may be maintained in white-tailed deer by congenital infection.
\end{abstract}

bovine viral diarrhea virus / BVDV transmission / Odocoileus virginianus / persistent infection / white-tailed deer

\section{INTRODUCTION}

Bovine viral diarrhea virus (BVDV), a pestivirus in the family Flaviviridae, employs different strategies to ensure survival and successful propagation in the mammalian host population. These strategies include the modification of the host's immune response, multiple direct and indirect routes of transmission, and establishment of persistently infected (PI) carrier animals

\footnotetext{
* Corresponding author: walzpau@auburn.edu
}

following transplacental infections in the first trimester of pregnancy $[30,31]$. Persistently infected cattle generally shed BVDV throughout their life and at much greater levels than acutely infected animals, resulting in a larger coefficient of infectiousness [31]. In addition, BVDV may efficiently cross species barriers and infect various mammalian hosts in the order Artiodactyla, which may be important in the pathogen's survival strategy [36].

The mammalian order Artiodactyla consists of 10 families, and evidence of infection 
with BVDV has been reported in the families Antilocapridae, Bovidae, Camelidae, Cervidae, Giraffidae, Suidae, and Tragulidae, including over 50 species $[13,21,34]$. Epidemiologically intriguing, persistent BVDV infections have been described in different species other than cattle, including domestic small ruminants, swine, alpacas, eland (Taurotragus oryx), lesser Malayan mouse-deer (Tragulus javanicus), and white-tailed deer (Odocoileus virginianus) [1, 5, 13, 18, 23]. However, little knowledge exists regarding the role of PI heterologous species in the epidemiology of BVDV. The virus was transmitted horizontally to two calves and vertically within a maternal line by PI lesser Malayan mouse-deer, demonstrating transmission of BVDV among heterologous PI hosts [32]. High seroprevalence rates were reported in Zimbabwean eland populations, in which a PI eland was found, suggesting endemic viral circulation [1]. In a PI white-tailed deer, levels of BVDV shedding from the nasal passages were similar to those found in PI cattle, suggesting that, given sufficient contact to susceptible animals, BVDV may be efficiently transmitted [23].

In North America, white-tailed deer are the most abundant free-ranging ruminant and home ranges extend from southern Canada to northern South America [3]. In this species, infections with BVDV following experimental and natural infections have been described [6, 23]. Bovine viral diarrhea infections in white-tailed deer have resulted in subclinical signs, pyrexia, lymphopenia, and reproductive disease $[26,27,33]$. Reproductive disease following experimental BVDV infections included abortion, embryonic resorption, fetal mummification, and stillbirth $[23,27]$. In contrast, all white-tailed deer in a recent study carried their pregnancies to term after infection with BVDV by cohabitation with PI cattle in the first trimester of gestation [24]. In that study, 4 of 7 pregnancies resulted in BVDV positive offspring, of which 3 were PI with BVDV indicating efficient interspecific transmission [24].

Understanding the ecology of BVDV, including host range and potential for transmission among different species, is vital to control programs in domestic and wild animal populations. In a North American pastoral environment, frequent contact of cattle and white-tailed deer is likely; however the risk of white-tailed deer to be a reservoir for BVDV also depends on maintenance of BVDV within deer populations. To date, knowledge about BVDV maintenance in white-tailed deer does not exist, prompting the present study, in which pregnant white-tailed deer were cohabitated with a PI fawn.

\section{MATERIALS AND METHODS}

\subsection{Animals}

The research described herein was performed under the approval of the Institutional Animal Care and Use Committee of Auburn University (2008-1340). Between 7th March and 11th April 2008, six female white-tailed deer were captured by cannon-net or dart-gun similarly to previously described methods $[15,28]$. For sedation after capture by cannon-net, $120 \mathrm{mg}$ of xylazine HCL (AnaSed $^{\circledR}$, Lloyd Laboratories, Shenandoah, IA, USA) and $150 \mathrm{mg}$ of tiletamine $\mathrm{HCl} /$ zolazepam $\mathrm{HCl}$ (Telazol, Ford Dodge Animal Health, Fort Dodge, IA, USA) were administered intramuscularly. Alternatively, $200 \mathrm{mg}$ of xylazine $\mathrm{HCl}$ and $250 \mathrm{mg}$ of tiletamine $\mathrm{HCl} /$ zolazepam $\mathrm{HCl}$ were administered by dart gun. Under sedation, blood and skin samples were collected to determine the deer to be free from BVDV or BVDV antibodies by serum and whole blood virus isolation, RT-nPCR, immunohistochemistry, and virus neutralization. Pregnancy examinations were performed by transrectal and/or transabdominal ultrasound. When possible, placentome or vesicle sizes, and/or fetal crown-to-rump lengths were recorded to assist in estimating fetal ages at exposure. The deer were transported to a 2.0 ha deer pen at the Captive Deer Research Facility at Auburn University in which two additional whitetailed deer were housed. Of these two deer, one was PI with a BVDV 1b strain (designated AU526) as result of the cohabitation of its dam with two PI cattle [24]. At the beginning of cohabitation, the PI deer was approximately 6.5 months old. Beginning in July 2008, the deer pen was searched for fawns daily. When a fawn was found, it was evaluated and whole blood, serum, skin biopsy (ear notch) and nasal swab samples were collected for virus isolation, RT-nPCR, ELISA, IHC, and virus neutralization. Fawns remained with their dams until all deer had given birth. When a fawn was positive for BVDV at initial testing or appeared unthrifty, further samples were collected approximately 3 weeks after birth. 
Following the cessation of parturitions, all adult deer and fawns that were negative for BVDV were euthanized. At euthanasia, blood samples were collected for virus isolation and virus neutralization procedures. When a fawn was found dead, additional blood and tissue samples were collected for virus isolation and IHC.

\subsection{Maternity testing}

A skin biopsy sample was collected from all adult and neonatal deer and stored at $-80{ }^{\circ} \mathrm{C}$ until testing was performed as previously described $[2,8]$. Briefly, DNA was isolated using a commercial kit (Qiagen DNeasy, Qiagen Genomics Inc., Bothell, Washington, USA) and PCR was used to amplify 13 microsatellite DNA loci from a panel optimized for use in whitetailed deer (BL25, BM6438, BM848, O, BM4208, BM6506, D, P, Cervid1, ILSTS011, INRA011, $\mathrm{N}, \mathrm{Q})$. The PCR products were loaded on an ABI 3130 automated DNA sequencer (Applied Biosystems, Foster City, CA, USA) and multilocus genotypes were constructed for all individuals using GENEMAPPER software (Applied Biosystems). Maternity was assigned for all fawns using a likelihood ratio method in the computer program CERVUS 3.0 ${ }^{1}$.

\subsection{Virus isolation}

From the adult deer, serum and whole blood samples obtained at the time of capture and euthanasia were tested by virus isolation. From fawns, virus isolations were performed on whole blood and nasal swab samples at birth; serum and whole blood samples at retesting; and serum and whole blood samples at euthanasia, as well as tissues (lymph nodes, spleen, thymus) collected at postmortem examination. Samples were assayed for BVDV by passage through MDBK cells, as has been described previously [12].

\subsection{Skin biopsy immunohistochemistry}

Immunohistochemical detection of BVDV antigen was performed on formalin-fixed paraffin-embedded skin biopsies collected at birth and retesting using the monoclonal antibody, 3.12F1. The 3.12F1 monoclonal antibody reacts with an epitope of the $\mathrm{E}^{\mathrm{RNS}}$ of BVDV that is shared by diverse BVDV isolates and therefore is a suitable target for the detection of a wide variety of isolates of BVDV. The IHC stain distribution in animals PI with BVDV is represented by diffuse

\footnotetext{
${ }^{1}$ www.fieldgenetics.com
}

staining in the epidermis and hair follicle epithelium; stain may also be present in the dermis and adnexal structures surrounding hair follicles [4]. Antigen distribution in white-tailed deer, PI with BVDV is analogous to that detected in PI cattle $[9,23]$.

\subsection{Antigen capture ELISA}

The BVDV antigen detection in skin biopsy samples was performed using a commercially available kit (IDEXX Laboratories, Westbrook, ME 04092, USA) developed for BVDV detection in bovine samples, according to the manufacturer's instructions. Presence or absence of BVDV within samples and classification as negative, suspect, or positive sample was established by using sample to positive $(\mathrm{S} / \mathrm{P})$ ratios of $<0.20,0.20-0.39$, or $>0.39$, respectively.

\subsection{Virus neutralization}

A standard virus neutralization microtiter assay was used for the detection and quantification of antibodies in serum of adult deer at capture and euthanasia, and from fawns at birth, retesting, and euthanasia. Sera were tested for neutralizing antibodies as previously described [12]. The test isolate used in the serum neutralization assay was BVDV AU526 which had been isolated from the PI fawn that exposed the pregnant does. The antibody titer was defined as the inverse of the highest dilution with complete inhibition of staining by the immunoperoxidase test.

\subsection{Reverse transcriptase polymerase chain reaction and sequencing}

Viral RNA was detected by a two-round rapidcycle PCR assay on whole blood samples, serum, and tissues from fawns; and serum samples from adult deer at capture and euthanasia. This RT-nPCR is characterized by increased sensitivity as compared to conventional RT-PCR and has been previously described in detail [11]. Briefly, RNA was isolated from samples using the QIAamp ${ }^{\circledR}$ viral RNA mini kit (Qiagen, Valencia, CA, USA) according to the manufacturer's instructions. All steps of the RT-nPCR were performed in a single-tube reaction. In the first round, the outer primers, BVD $100 \quad\left(5^{\prime}\right.$-GGCTAGCCATGCCCTT AG-3') and HCV 368 (5'-CCATGTGCCATGTAC AG- $3^{\prime}$ ) amplified a 290 base pair sequence of the $5^{\prime}$ untranslated region of the viral genome. In the second round of the reaction, the inner primers BVD 180 (5'-CCTGAGTACAGGGDAGTCGTCA-3') and HCV 368 amplified a 213 base pair sequence 
within the first amplicon. After completion of the PCR cycle, $5 \mu \mathrm{L}$ of the RT-nPCR products were separated by $1.5 \%$ agarose gel electrophoresis. Ethidium bromide staining allowed visualization of the RT-nPCR using an ultraviolet transilluminator. On RT-nPCR positive samples, sequence analysis was performed on aliquots of the RT-nPCR products carried out in triplicate.

If positive for BVDV on agar gel electrophoresis, samples were purified using the QIAquick ${ }^{\circledR}$ PCR purification kit (Qiagen) according to the manufacturer's specifications and sequenced by automated dye terminator nucleotide sequencing using both the $5^{\prime}$ and $3^{\prime}$ primers (BVD 180 and HCV 368, respectively). Consensus sequences were determined for each sample using Align $X^{\circledR}$ computer software (Vector NTI Suite 7.1, InforMax, Inc., Bethesda, MD, USA) and compared to nucleotide sequences of BVDV AU526.

\section{RESULTS}

In June, 2008, the PI deer used for exposure died at approximately 10 months of age and BVDV antigen was detected by IHC in skin sample biopsies. A total of 10 fawns (2 singlets and 8 twins) were born to the 6 does, which is in agreement with previously reported rates of reproductive success in white-tailed deer $[22,35]$. All fawns were born between 4th July and 16th August 2008, which corroborated the estimated days of birth based on initial ultrasound examinations of the captured does. All twin fawns were adequate in weight and appearance; however, both singlet fawns were below the normal weight reported for whitetailed deer fawns in Alabama [14].

At initial testing, evidence of BVDV infection was detected in two fawns, one a singlet (fawn No. 21) and the other a twin (No. 19) (Tab. I). Serum from both fawns was positive by RT-nPCR assay and BVDV was isolated from the buffy coat of the singlet (No. 21). While all fawns were negative on nasal swab virus isolation and ELISA, the singlet fawn was also positive on skin sample IHC. An additional singlet fawn (No. 22) appeared small at birth and had an ill-thrifty appearance. From this fawn and the two fawns positive for BVDV at birth (Nos. 19 and 21), additional samples were collected to assess their status as PI. These sam- ples mirrored the initial results as the RT-nPCR was positive in 2 fawns, the virus isolation from the buffy coat was positive in 1 fawn (No. 21), and the ill-thrifty fawn (No. 22) was negative for BVDV. Both singlet fawns (Nos. 21 and 22) died within 1 month of birth, and further evidence of BVDV infection was identified in fawn No. 21 as indicated by IHC. According to the repeated isolation of $\mathrm{BVDV}$ and positive IHC results, fawn No. 21 was determined to be PI with BVDV. However, as virus was not isolated from the RT-nPCR positive fawn (No. 19), its status of infection was considered uncertain. Therefore, additional samples were collected from fawn No. 19 at approximately 5 months of age, which resulted in negative results using virus isolation and RT-nPCR procedures.

Based on pregnancy ultrasound examinations and day of birth, first exposure of the doe that gave birth to the PI fawn (No. 21) was at approximately 41 days of gestation. For all does that did not give birth to PI offspring, first cohabitation with the PI deer occurred from day 63 or later. Virus was not detected in adult deer at capture or euthanasia or the remaining fawns at euthanasia. Cohabitation of the pregnant does with the PI deer resulted in seroconversion in all adult deer with antibody titers from 1:128 to $1: 512$ at euthanasia; approximately 6-8 months after the PI deer had died (Tab. II). The greatest antibody titers were detected in the dams of the two singlet fawns, of which one was determined to be PI.

\section{DISCUSSION}

This study demonstrates for the first time that BVDV may be transmitted among white-tailed deer and result in the birth of PI offspring. Despite evidence of persistent infection in only one fawn (No. 21), seroconversion in all exposed does indicates that efficient transmission of BVDV occurred as a result of exposure to a PI deer during pregnancy. Furthermore, the study emphasizes that, despite low survival in PI white-tailed deer and substantially reduced life expectancy, a fawn from a previous year may survive long enough to be present during the early gestational period of the following year. 
Table I. Results of virological assays on fawns.

\begin{tabular}{|c|c|c|c|c|c|c|c|c|c|c|c|c|}
\hline & Fawn ID & & 13 & 14 & 15 & 16 & 17 & 18 & 19 & 20 & 21 & 22 \\
\hline \multirow{6}{*}{ Birth } & Serum & VN & 4096 & 4096 & 2048 & 4096 & 2048 & 8192 & 2048 & 4096 & 16384 & 4096 \\
\hline & & $\mathrm{nPCR}$ & - & - & - & - & - & - & + & - & + & - \\
\hline & Nasal swab & VI & - & - & - & - & - & - & - & - & - & - \\
\hline & Buffy coat & VI & - & - & - & - & - & - & - & - & + & - \\
\hline & Skin & $\mathrm{IHC}$ & - & - & - & - & - & - & - & - & + & - \\
\hline & & ELISA & - & - & - & - & - & - & - & - & - & - \\
\hline \multirow[t]{5}{*}{ Re-test } & Serum & $\mathrm{VN}$ & & & & & & & 512 & & 4096 & 1024 \\
\hline & & VI & & & & & & & - & & - & - \\
\hline & & $\mathrm{nPCR}$ & & & & & & & + & & + & - \\
\hline & Buffy coat & VI & & & & & & & - & & + & - \\
\hline & Skin & $\mathrm{IHC}$ & & & & & & & - & & + & - \\
\hline \multirow[t]{5}{*}{ Euthanasia } & Serum & $\mathrm{VN}$ & 32 & 256 & 1024 & 2048 & 256 & 2048 & 1024 & 512 & & \\
\hline & & VI & - & - & - & - & - & - & - & - & & \\
\hline & & $\mathrm{nPCR}$ & - & - & - & - & - & - & - & - & & \\
\hline & Buffy coat & VI & - & - & - & - & - & - & - & - & & \\
\hline & Tissues & VI & - & - & - & - & - & - & - & - & & \\
\hline
\end{tabular}

Table II. Results of virological assays on does.

\begin{tabular}{|c|c|c|c|c|c|}
\hline ID of doe & $\begin{array}{l}\text { BVDV } \\
\text { serotiter at } \\
\text { capture }\end{array}$ & $\begin{array}{l}\text { BVDV } \\
\text { serotiter at } \\
\text { re-test }\end{array}$ & $\begin{array}{l}\text { Gestational } \\
\text { age at } \\
\text { exposure }^{\text {a }}\end{array}$ & $\begin{array}{l}\text { ID of } \\
\text { offspring }\end{array}$ & $\begin{array}{l}\text { Status of } \\
\text { offspring }\end{array}$ \\
\hline 31 & $<4$ & 512 & 41 days & 21 & Persistently infected \\
\hline 32 & $<4$ & NA & 66 days & 18 and 19 & $\begin{array}{c}\text { Seropositive, } 19 \text { RT-nPCR } \\
\text { positive at birth }\end{array}$ \\
\hline 33 & $<4$ & 128 & 75 days & 17 and 20 & Seropositive \\
\hline 34 & $<4$ & 512 & 63 days & 22 & Seropositive \\
\hline 35 & $<4$ & 128 & 104 days & 13 and 14 & Seropositive \\
\hline 36 & $<4$ & 128 & 114 days & 15 and 16 & Seropositive \\
\hline
\end{tabular}

${ }^{\text {a }}$ Calculation based on 200 days gestation and day of first contact with PI deer (day of capture).

${ }^{\mathrm{b}}$ Status of passive transfer unknown at time of sample collection.

Maintenance of BVDV within free-ranging white-tailed deer populations would depend on the presence of BVDV shedders, such as PI deer during the critical gestational period. According to the rose-petal hypothesis, female offspring establish home ranges that tend to overlap that of their mother [25]. As successive generations of female offspring are born, the spatial distribution of a group of related individuals will continue to expand like the petals of a rose. These cohesive social groups consisting of related females may be particularly susceptible to
BVDV infection once exposed. Female whitetailed deer typically exhibit very low rates $(<5 \%)$ of dispersal [10], suggesting that female PI offspring have strong potential to transmit BVDV to related pregnant females within their home range. Within these matrilineal groups, there is frequent close contact among deer, as was emulated in this study, and BVDV transmission may be similarly efficient. Intramatrilineal BVDV maintenance in white-tailed deer may be comparable to the transmission and maintenance of BVDV in domesticated alpacas, where 
PI crias remain with their dam during the subsequent breeding period, therefore efficiently infecting other susceptible females [17]. The efficiency of transfer among matrilineal groups will ultimately be a function of the BVDV immune status of the population, the social organization and genetic relatedness within the population, and the management of the population by harvest. Deer populations that are subjected to high rates of antlerless harvest may exhibit reduced spatial and genetic structuring [7], which could reduce the potential for maintenance of BVDV within a population. In contrast to females, most male white-tailed deer disperse between 12 and 18 months of age. Dispersal distances are normally between 5 and $10 \mathrm{~km}$, but can be as great as $40 \mathrm{~km}[19,20]$. This high rate of dispersal suggests that male PI fawns that survive to dispersal age have greater potential to transmit BVDV to unrelated groups of deer across a greater geographical area than females; however, orphaned male fawns exhibit much lower rates of dispersal than their unorphaned counterparts [16]. Theoretically, an increase in the number of orphaned fawns by antlerless harvest would reduce the probability of a male PI fawn dispersing to a new area.

Results of this and other studies demonstrate the potential for maintenance of BVDV in white-tailed deer populations as indicated by viral shedding from PI deer, which is similar to cattle [23], and transmission among whitetailed deer. However, there likely are regional variations in the extent of BVDV maintenance that depend on population density and its influence on contact rates among deer. Increasing population densities result in greater chances for contact among deer and therefore increased transmission potential. Supplemental winter feeding may be an important factor in maintenance of BVDV in white-tailed deer, as this artificial commingling of deer occurs at a time when fetuses may be susceptible to BVDV and become PI. Any deer management practices that increase deer densities or rates of contact among deer have the potential to increase the potential for maintenance of BVDV within a population, as has been described for maintenance of bovine tuberculosis in white-tailed deer populations [29].
To date, information on the susceptible gestational age for persistent infections in whitetailed deer is unknown. According to the estimated gestational age based on ultrasound examination and the date of birth of the PI fawn (No. 21), transplacental infection occurred at 41 days of gestation based upon a gestational length of 200 days for white-tailed deer in Alabama. This is corroborated by previous studies, where PI fawns were born to whitetailed deer intranasally inoculated on days 43 or $42-49$, respectively $[23,27]$. Based on the shorter gestation length in white-tailed deer as compared to cattle, a gestational age below 67 days was suspected to be the most susceptible time at which white-tailed deer fetuses may become PI [27]. Further research is necessary to substantiate these extrapolations, as the critical gestational age is important epidemiological information that likely influences BVDV maintenance in white-tailed deer.

In a recent study, experimental inoculation of pregnant white-tailed deer with a strain of BVDV isolated from white-tailed deer resulted in severe reproductive disease [27]. In contrast, all does in this study maintained pregnancies and gave birth to live fawns. Similar observations were made in another study, where only 1 of 7 pregnancies resulted in birth of stillborn fawns, and live fawns were born to the remaining 6 does after cohabitation with PI cattle during the first trimester of pregnancy [24]. Differences in these findings may be due to viral isolates, as BVDV strains of bovine rather than cervine origin were used in studies by this group. Furthermore, in the study by Ridpath et al. [27], the intranasal route of infection was used which likely resulted in viral challenge dynamics much different from exposures to PI deer, as was used in the present study.

The findings of this study add to a body of knowledge that indicates that white-tailed deer have the potential to become a reservoir for BVDV. However, most of the current knowledge on BVDV in white-tailed deer is from experimental research rather than observations in free-ranging populations. Regional variations in deer management and varying population dynamics emphasize the need for further systematic evaluation of BVDV in deer. 
Infections with BVDV in white-tailed deer populations may have a negative impact on health and welfare, but should also be considered where BVDV control programs are planned.

Acknowledgements. This study was funded by Animal Health Research, Auburn University. The authors gratefully acknowledge $\mathrm{Mr}$ Chad Newbolt and $\mathrm{Mr}$ Nathan Worthington for their assistance with the capture of white-tailed deer. The authors also acknowledge the technical staff of the BVDV laboratories at Auburn University, especially Ms Yijing Zhang, Mr Andrew Eason, and Ms Terri Hathcock.

\section{REFERENCES}

[1] Anderson E.C., Rowe L.W., The prevalence of antibody to the viruses of bovine virus diarrhoea, bovine herpes virus 1, rift valley fever, ephemeral fever and bluetongue and to Leptospira sp. in freeranging wildlife in Zimbabwe, Epidemiol. Infect. (1998) 121:441-449.

[2] Anderson J.D., Honeycutt R.L., Gonzales R.A., Gee K.L., Skow L.C., Gallagher R.L., et al., Development of microsatellite DNA markers for the automated genetic characterization of white-tailed deer populations, J. Wildl. Manage. (2002) 66:67-74.

[3] Baker R.H., Classification and distribution, in: Halls L.K. (Ed.), White-tailed deer ecology and management, Stackpole Books, Harrisburg, PA, 1984, pp. 1-18.

[4] Brodersen B.W., Immunohistochemistry used as a screening method for persistent bovine viral diarrhea virus infection, Vet. Clin. North Am. Food Anim. Pract. (2004) 20:85-93.

[5] Carman S., Carr N., DeLay J., Baxi M., Deregt D., Hazlett M., Bovine viral diarrhea virus in alpaca: abortion and persistent infection, J. Vet. Diagn. Invest. (2005) 17:589-593.

[6] Chase C.C., Braun L.J., Leslie-Steen P., Graham T., Miskimins D., Ridpath J.F., Bovine viral diarrhea virus multiorgan infection in two white-tailed deer in southeastern South Dakota, J. Wildl. Dis. (2008) 44:753-759.

[7] Comer C.E., Kilgo J.C., D’Angelo G.J., Glenn T.C., Miller K.V., Fine-scale genetic structure and social organization in female white-tailed deer, J. Wildl. Manage. (2005) 69:332-344.

[8] DeYoung R.W., Demarais S., Honeycutt R.L., Gonzales R.A., Gee K.L., Anderson J.D., Evaluation of a DNA microsatellite panel useful for genetic exclusion studies in white-tailed deer, Wildl. Soc. Bull. (2003) 31:220-232.

[9] Duncan C., Ridpath J., Palmer M.V., Driskell E., Spraker T., Histopathologic and immunohistochemical findings in two white-tailed deer fawns persistently infected with bovine viral diarrhea virus, J. Vet. Diagn. Invest. (2008) 20:289-296.

[10] Dusek G.L., Mackie R.J., Herriges J.D. Jr, Compton B.B., Population ecology of white-tailed deer along the lower Yellowstone River, Wildl. Monogr. (1989) 104:1-68.

[11] Givens M.D., Galik P.K., Riddell K.P., Stringfellow D.A., Brock K.V., Bishop M.D., et al., Validation of a reverse transcription nested polymerase chain reaction (RT-nPCR) to detect bovine viral diarrhea virus (BVDV) associated with in vitro-derived bovine embryos and co-cultured cells, Theriogenology (2001) 56:787-799.

[12] Givens M.D., Heath A.M., Brock K.V., Brodersen B.W., Carson R.L., Stringfellow D.A., Detection of bovine viral diarrhea virus in semen obtained after inoculation of seronegative postpubertal bulls, Am. J. Vet. Res. (2003) 64:428-434.

[13] Grondahl C., Uttenthal A., Houe H., Rasmussen T.B., Hoyer M.J., Larsen L.E., Characterisation of a pestivirus isolated from persistently infected mousedeer (Tragulus javanicus), Arch. Virol. (2003) 148:1455-1463.

[14] Haugen A.O., Breeding records of captive whitetailed deer in Alabama, J. Mammal. (1959) 40:108-113.

[15] Hawkins R.E., Martoglio L.D., Montgomery G.G., Cannon-netting deer, J. Wildl. Manage. (1968) 32:191-195.

[16] Holzenbein S., Marchinton R.L., Emigration and mortality in orphaned male white-tailed deer, J. Wildl. Manage. (1992) 56:147-153.

[17] Kim S.G., Anderson R.R., Yu J.Z., Zylich N.C., Kinde H., Carman S., et al., Genotyping and phylogenetic analysis of bovine viral diarrhea virus isolates from BVDV infected alpacas in North America, Vet. Microbiol. (2009) 136:209-216.

[18] Loken T., Ruminant pestivirus infections in animals other than cattle and sheep, Vet. Clin. North Am. Food Anim. Pract. (1995) 11:597-614.

[19] Long E.S., Diefenbach D.R., Rosenberry C.S., Wallingford B.D., Grund M.R.D., Forest cover influences dispersal distance of white-tailed deer, J. Mammal. (2005) 86:623-629.

[20] McCoy J.E., Hewitt D.G., Bryant F.C., Dispersal by yearling male white-tailed deer and implications for management, J. Wildl. Manage. (2005) 69:366-376. 
[21] Nettleton P.F., Pestivirus infections in ruminants other than cattle, Rev. Sci. Tech. (1990) 9:131-150.

[22] Ozoga J.J., Maximum fecundity in supplementally-fed northern Michigan white-tailed deer, J. Mammal. (1987) 68:878-879.

[23] Passler T., Walz P.H., Ditchkoff S.S., Givens M.D., Maxwell H.S., Brock K.V., Experimental persistent infection with bovine viral diarrhea virus in white-tailed deer, Vet. Microbiol. (2007) 122:350-356.

[24] Passler T., Walz P.H., Ditchkoff S.S., Brock K.V., Deyoung R.W., Foley A.M., Givens M.D., Cohabitation of pregnant white-tailed deer and cattle persistently infected with bovine viral diarrhea virus results in persistently infected fawns, Vet. Microbiol. (2009) 134:362-367.

[25] Porter W.F., Mathews N.E., Underwood H.B., Sage R.W., Behrend D.F., Social-organization in deerimplications for localized management, Environ. Manage. (1991) 15:809-814.

[26] Ridpath J.F., Mark C.S., Chase C.C., Ridpath A.C., Neill J.D., Febrile response and decrease in circulating lymphocytes following acute infection of white-tailed deer fawns with either a BVDV1 or a BVDV2 strain, J. Wildl. Dis. (2007) 43:653-659.

[27] Ridpath J.F., Driskell E.A., Chase C.C., Neill J.D., Palmer M.V., Brodersen B.W., Reproductive tract disease associated with inoculation of pregnant whitetailed deer with bovine viral diarrhea virus, Am. J. Vet. Res. (2008) 69:1630-1636.

[28] Saalfeld S.T., Ditchkoff S.S., Survival of neonatal white-tailed deer in an exurban population, J. Wildl. Manage. (2007) 71:940-944.
[29] Schmitt S.M., O’Brien D.J., Bruning-Fann C.S., Fitzgerald S.D., Bovine tuberculosis in Michigan wildlife and livestock, Ann. N.Y. Acad. Sci. (2002) 969:262-268.

[30] Schweizer M., Matzener P., Pfaffen G., Stalder H., Peterhans E., "Self" and "nonself" manipulation of interferon defense during persistent infection: bovine viral diarrhea virus resists alpha/beta interferon without blocking antiviral activity against unrelated viruses replicating in its host cells, J. Virol. (2006) 80:6926-6935.

[31] Thurmond M.C., Virus transmission, in: Goyal S.M., Ridpath J.F. (Eds.), Bovine viral diarrhea virus diagnosis, management, and control, Blackwell Publishing, Ames, IA, 2005, pp. 91-104.

[32] Uttenthal A., Hoyer M.J., Grondahl C., Houe H., van Maanen C., Rasmussen T.B., Larsen L.E., Vertical transmission of bovine viral diarrhoea virus (BVDV) in mousedeer (Tragulus javanicus) and spread to domestic cattle, Arch. Virol. (2006) 151:2377-2387.

[33] Van Campen H., Williams E.S., Edwards J., Cook W., Stout G., Experimental infection of deer with bovine viral diarrhea virus, J. Wildl. Dis. (1997) 33:567-573.

[34] Van Campen H., Froelich K., Hofmann M., Pestivirus infections, in: Williams E.S., Barker I.K. (Eds.), Infectious diseases of wild mammals, Iowa State University Press, Ames, IA, 2001, pp. 232-244.

[35] Verme L.J., Maternal investment in white-tailed deer, J. Mammal. (1989) 70:438-442.

[36] Vilcek S., Nettleton P.F., Pestiviruses in wild animals, Vet. Microbiol. (2006) 116:1-12. 